\title{
Transmedial Ekphrasis. From Analogic to Digital Formats
}

\section{Asunción López-Varela Azcárate}

Universidad Complutense de Madrid, Spain

doi: 10.7358/ijtl-2015-001-lope

alopezva@ucm.es

\begin{abstract}
Art is a way to give autonomy to sensorial experiences beyond natural perception. Thus, it serves as a form of meta-representation, a model for raising awareness in recognition and cognition. In the West, the first discussions on aesthetics, coming mainly from ancient Greece, inscribed art within analogy and representation (mimesis) and, simultaneously, within telling and narration (diegesis). The term ekphrasis was used to describe the skills that enabled the translation of artistic content and its expression in different formats, whether painting, sculpture, oral poetry, writing, dance, performance and so on. Until the $20^{\text {th }}$ century, ekphrasis was mainly contemplated as the verbalization of aesthetic aspects from visual media (mostly painting and sculpture). In this paper, I examine Lewis Carroll's poem "Jabberwocky" included in the novel Through the LookingGlass, and compare it to Jan Švankmajer's 1971 movie by the same title. I also explore Simon Biggs' 2010 installation reRead, inspired in the novel. The three works are used as examples of art works which break analogic principles and bring to the fore, each in a different medium, the metamorphosis of ekphrastic processes ${ }^{1}$.
\end{abstract}

Keywords: Ekphrasis; Jabberwocky; Lewis Carroll; Jan Švankmajer; Simon Biggs; Transmedia; digital formats.

\section{INTRODUCTION}

The use of analogy lies at the root of comparisons between the arts in early Western thought. The Greek Simonides of Ceos, for instance, defined poetry as painting that speaks. To him, painting was silent poetry (Markiewwicz 1987,

1 I am indebted to Prof. Lars Elleström (Linneaus University, Sweden) for bringing Jan Švankmajer's work to my attention. For more information on Švankmajer's "Jabberwocky", see Elleström's recent volume Media Transformation (2014).

International Journal of Transmedia Literacy - 1.1 - December 2015

http://www.ledonline.it/transmedialiteracy/ 
535; Campbell 1991, 357, 363, 497). The combination of words and of colours was believed to follow bio-physical ordering principles. Thus, in the Theatatus Socrates relates: "Methought that I too had a dream, and I heard in my dream that the primeval letters or elements out of which you and I and all other things are compounded, have no reason or explanation." (Drucker 1995, 111) The Greek word for alphabet, stoicheia, also carries the meaning ordered elements and the cosmological and atomistic analogies, working at the macro and micro levels, attached to the term. One of the first descriptions of the analogic relations between the elements of the world [ $\sigma \tau 0 \mathrm{\chi} \chi \varepsilon \hat{i o v}]$, letters, numbers, music and the harmony of the universe can be discerned in Plato's dialogue Timaeus:

It is necessary to consider, what was the nature of fire, water, air and the earth before the birth of heaven and what were they then. By now nobody explained their origin,

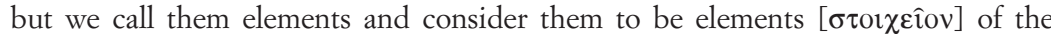
Universe as if we knew what the fire was and what was the rest, but it seemed clear to each at least a little an intelligent man in mind that there is no ground to compare it with some type of syllables. (531)

In the same paragraph, following the Pythagorean tradition, Plato goes on to describe the creation of the world as a recursive modelling of parts. If for Plato, words were inferior to images for reproducing the mimetic faithfulness of representation (Krieger 1992, 14) Aristotle's Poetics draws attention to the use of analogy within the different arts, each varying in relation to the medium, subject (also term agent by some translators of Aristotle) and manner. The Greek philosopher develops the parallel between poetry and painting and claims that although the object of both arts is the imitation of human nature in action, their means for achieving this are different. Poetry uses language, rhythm and harmony, and painting uses colour and form. Aristotle explains genre division with regards to the subject/agent who performs the analogy or mimetic act (1987, Parts III-IV).

Similarly, in Book One of De Rerum Natura the Roman poet and philosopher Lucretius draws the analogy between atoms and letters to explain the idea of structure: "Atoms then are to bodies what letters are to words: heterogeneous, deviant, and combinatory" (Gale 2007, 35; Rasula and McCaffery 1998, 532). The close relation between poetry and painting, the latter being 'silent poetry', and the idea of perfection that distinguishes the fine arts was captured more importantly in the work of the Roman scholar Horace's Ars poëtica as ut pictura poesis (Markiewicz 1987, 535).

The repetition of these patterns gradually became assimilated as ordering principles within certain semiotic correlations in the cultural unconscious, becoming part of languages, writing systems, and other forms of cultural representation (i.e. geometry, algebra, and so on). (López-Varela 2014a) Thus, 
ekphrasis was initially defined as a sort of modelling mechanism for drawing analogies between words and images, the first creating a vivid description and evocation as if placed before the listener's or the reader's inner eye.

The prevalence of the word was also reinforced by the spread of JudeoChristian traditions across Europe and the Mediterranean. This devaluation of painting in favour of the culture of the 'Book' (referring to the Bible which serves as basis for the Jewish, Christian and Muslim religions) can be seen, for instance, in the absence of painting from institutionalized Western forms of knowledge, as developed in the first European universities which taught the seven liberal arts (Trivium - grammar, rhetoric, and dialectic - and the Quadrivium - arithmetic, geometry, astronomy and music). Painting and sculpture were considered manual rather than intellectual labor and therefore classified with the mechanical arts.

In the Renaissance, several attempts were made by painters and sculptors to reclaim a place for the visual arts and their status as artists, rather than artisans and imitators. For example, Leonardo da Vinci's Paragone (ca. 1510) reversed Simonides' comparison by claiming that if painting is "mute poetry," then poetry is "blind painting." $(1992,209)$ Despite these efforts, in the Western world and till the $18^{\text {th }}$ century, most visual pieces - engravings, paintings, and so on - were inspired in written texts, many taken from religious passages. Illustrations had a secondary role and were frequently used to clarify or embellish the supremacy of the written word.

In the $18^{\text {th }}$ and early $19^{\text {th }}$ centuries, with the onset of the new rhythmic patterns of industrialization, inquiries on the representational differences between the arts were directed toward the temporal, rather than the spatial aspects of analogy. In Laokoon (1766), the German writer Gotthold Ephraim Lessing emphasized the ability of poetry to excite mental pictures in a temporal sequence, thus creating the illusion of reality. Lessing expresses his belief that the visual artist is more limited than the poet as he can only captures one point of view in a particular instant in time. Painting functions within simultaneity, as a static object, while poetry moves on the axis of succession, and is thus better able to create an illusion of reality. (Mitchell 1986, 97)

The idea of the complete work of art began to emerge at this time. The term Gesamtkunstwerk was first used by the German writer and philosopher Karl Friedrich Eusebius Trahndorff (1827) in his Ästhetik oder Lebre von Weltanschauung und Kunst, and later reformulated by Richard Wagner in accordance with his aesthetic ideals regarding music. He envisioned opera as a fusion of music, poetry and painting, and created a complex web of leitmotifs and recurring themes associated with the characters and themes of his compositions, many of them inspired in stories from the Germanic tradition and Arthurian legends. 
The Parnassian turn in late 19th century French poetry owes much to the visual arts and Greek mythology, including the poems by Théodore de Banville, Stéphane Mallarmé, Paul Verlaine, under the influence of Théophile Gautier and Charles Baudelaire (Wettlaufer 2003, 64-66). In Great Britain, work by the romantic poet William Blake and Victorian authors like Algernon Charles Swinburne, or the pre-Raphaelite Dante Gabriel Rossetti and his sister Christina, cultivated both the pictorial and the poetic, drawing aesthetic correspondences between the two in order to incorporate sensorial aspects from human real life experiences in their art works ${ }^{2}$. Similarly, Mary Ann Evans (George Eliot) wrote many of her descriptions under the influence of John Ruskin's Modern Painters (1843).

In the $20^{\text {th }}$ century the debate on art and aesthetics became institutionalized, and most discussions came from scholars and academics. The contemporary usage of the term ekphrasis was coined by Leo Spitzer in his analysis of Keats's poem "Ode on a Grecian Urn" (1955), inspired by a painting by Claude Lorrain. Spitzer defined ekphrasis as "the poetic description of a pictorial or sculptural work of art, which description implies, in the words of Théophile Gautier, 'une transposition d'art', the reproduction through the medium of words of sensuously perceptible objets d'art (ut pictura poesis)." (Spitzer 1955, 207)

As 'description', ekphrasis continued to emphasize the role of words in drawing the analogy, but following Gautier, Spitzer speaks of 'transposition' of art, acknowledging changes in the spatial configurations (position) depending on the medium. For other scholars, as for Aristotle or Gotthold Ephraim Lessing, the difference was not so much on the spatial, but on the temporal patterns. Thus, for Heidegger's pupil, the German philosopher Hans-Georg Gadamer, poetic expression captures the original idea/emotion by echoing biophysical perceptual rhythms in alliteration, homonymy, synonymy, and by means of contrastive variations such as antonyms, negative parallelisms and other defamiliazing techniques. (Gadamer 1960) The term 'defamiliarization' had entered the academic milieu via Russian Formalism and, to a certain extent, it indicated that the declarative value of art and its mimetic and analogic qualities began to be questioned.

2 Many artists have acknowledged the inspiration of visual compositions of various kinds upon their works. For example, E.T.A. Hoffman, Victor Hugo, Edgar Allan Poe, Honore de Balzac, Nathaniel Hawthorne, Emilia Pardo Bazán, Rudyard Kipling, Oscar Wilde, Antón, P. Chéjov, Grabiele D’Annunzio, Guy de Maupassant, Rainer Maria Rilke, Pio Baroja, Edith Wharton, Henri Michaux, and more recently Günter Grass, and Leonora Carrington or José Saramago, among others. graphic poems: The interplay between text and image manifest itself in poems such as George Herbert's "The Altar", Dylan Thomas's "Vision and Prayer", Lewis Carroll's "Long and Sad Tail of the Mouse", e. e. cummings's "L(a", Edwin Morgan's "Siesta of a Hungarian Snake," François Rabelais's "epilenie," or Guillaume Apollinaire's "Il pleut". 
As interest shifts towards the temporal aspects of analogy (López-Varela 2004), definitions of ekphrasis emphasize the mechanisms used to "interrupt the temporality of discourse, to freeze it during its indulgence in spatial exploration" (Krieger 1992, 7; Heffernan 1993, 3) discussed as a "pregnant moment in painting," (Steiner 1982, 41) still an attempt to imitate the visual arts by describing a static moment.

\section{THE VICTORIAN VIEW ON EKPHRASIS}

The use of text and images became widespread during the Victorian period, a time when the model of analogy became widespread in realism, and was simultaneously questioned, as seen for instance in the persistent metaphor of the looking-glass. The mirror becomes the center of attention in many Victorian and pre-Raphaelite paintings, as well as in early daguerreotypes and photographs. The looking glass problematizes the concept of mimesis, creating a confusion between the real and the reflected. This inquiry takes place at a time when realism reaches its zenith, questioning the reversibility between the real and its shadow or its mirror reflection. In literature, the most important critique of the realist model is the novel Through the Looking-Glass, and What Alice Found There (1872) by the Reverend Charles Lutwidge Dodgson, English writer, logician and mathematician, also known as Lewis Carroll, a pseudonym created by the play of words (Latinizing his first and middle names and reversing their order). This inquiry into the real and its reflection, sometimes interpreted as a shadow (or copy of the real) continues in Robert Louis Stevenson's novella The Strange Case of Dr Jekyll and Mr. Hyde (1886). A deeper questioning of the 'fringe' (to use the title of a contemporary television serial) between what might be two connected worlds begins to take place in early $20^{\text {th }}$ century under the influence of psychoanalysis. Under Carl Jung's view, the shadow may refer to an unconscious aspect of the personality which the conscious ego does not identify in itself (it rejects it or remains ignorant of its non-desirable aspects), or to the entire unconscious (Jung 1938, 131). One the most popular examples of psychological narcissism is James Matthew Barrie's character Peter Pan.

In this paper, I concentrate on a poem entitled "Jabberwocky" included in Carroll's Through the Looking-Glass. My purpose is to compare it to Jan Švankmajer's 1971 movie by the same title, and to Simon Biggs' 2010 installation reRead. The three works are used in this paper as examples of art works whose purpose is to break analogic principles in order to surprise their audiences and call attention to the way representation functions. In doing so, they bring to the 
fore, each in a different medium, the metamorphosis of ekphrastic processes.

In the section of the novel where "Jabberwocky" is included, Alice is talking to the white king and queen, presented as chess pieces, and finds a book written in a strange language that seems to make sense only when read through a looking-glass in an inverted manner. According to Michael Bute y Brian Talbot, Carroll's poem may have been inspired by a legend from Sunderland, a region where Carroll lived in his childhood. The legend told the story of John Lambton, inheritor of a property under the same name near Durham. After his return from the crusades, Lambton had to fight a giant dragon-worm who had appropriated his father's land. He was able to beat the dragon with the help of a local witch, but a curse arose that was to last for nine generations in which the male heirs of the family were to die some kind of violent or accidental death. The legend was transmitted in the form of a ballad, sung in the local Mackem dialect, close to the Scottish language but with reminiscences of old English. Another possible source for the poem was a ballad by Friedrich de la Motte Fouqué, translated into English in 1846 by Menella Bute Smedley, one of Carroll's relatives. In this, the monster resembles a griffon. Other sources mention that the 'Tumtum tree' recalls some of the trees in the gardens of Christ Church at Oxford University, where Carroll taught mathematics, and that the purpose of the poem would have been to satirize Oxford snobbish and pretentious criticism by creating a parody of the archaic prosody and morphology of the English language, and mocking epic pretensions with a monster-slaying heroic plot (Gardner 1999, 154).

The 1871 illustrations of "Jabberwocky", by John Tenniel, reflect Victorian fascination for evolutionism and paleontology, since the dragon reminds of a pterodactyl, a hybrid flying creature, half an insect, half a lizard, with a sort of crest, the body covered by hair, and some kind of tense membranes of muscle fiber that served them as wings (Gardner 1999, 196). The title reflects this hybrid nature, made up of a polysemic cluster of two words, 'jabber' (unintelligible jargon), as well as 'jab' (poke sharply or punch with short quick blows), and 'wocky', meaning perhaps the 'wock' (or wok) where words and fried together, carrying also resonances to 'wacky' (funny or amusing in a sort of peculiar and stupid way).

The first stanza of "Jabberwocky" appeared for the first time in 1855 under the title "Stanza of Anglo-Saxon Poetry", when Carroll was twentythree. It was published in Mischmasch, a journal belonging to the Dodgson family. Apparently, Carroll revised the stanza before extending it into a poem (Gardner 1999, 191-192). The final version has seven stanzas in rimed iambic tetrameter (although the last stanzas have only three feet instead of four). The words are combined by means of coinages of multiple roots, suffices and prefixes, and that this 'portmanteau' technique (the terms derives from 'port- 
manteau luggage', a piece of luggage with two compartments that comes from the French 'to carry' and 'coat') multiplies their connotations, as Carroll himself explained. For instance, 'furious' and 'fuming' becomes 'frumious'. Similarly, 'gallop' and 'triumphant' yield 'galumphing'. (Gardner 1999, 195-196)

It can be appreciated that many words are onomatopoeic, that is, their meaning can be inferred from associations to their pronunciation and to other natural sounds, thus working on principles of analogy. However, these combinations show that words are more than abstract symbols, and that they retain many iconic and indexical features. Many words in the poem function morphologically as verb, adverb or noun, a fact that again multiplies their meanings.

'Twas brillig, and the slithy toves Did gyre and gimble in the wade; All mimsy were the borogoves, And the mome raths outgrabe.

"Beware the Jabberwock, my son! The jaws that bite, the claws that catch! Beware the Jubjub bird, and shun The frumious Bandersnatch!"

He took his vorpal sword in hand: Long time the manxome foe he soughtSo rested he by the Tumtum tree, And stood awhile in thought.

And as in uffish thought he stood, The Jabberwock, with eyes of flame, Came whiffling through the tulgey wood, And burbled as it came!

One, two! One, two! And through and through

The vorpal blade went snicker-snack!

He left it dead, and with its head

He went galumphing back.

"And hast thou slain the Jabberwock?

Come to my arms, my beamish boy!

O frabjous day! Calloob! Callay!"

He chortled in bis joy.

'Twas brillig, and the slithy toves

Did gyre and gimble in the wabe;

All mimsy were the borogoves,

And the mome raths outgrabe. 
It is interesting that the first and last stanzas are practically identical, with the exception of one letter that changes from d to b ('wade' to 'wabe'). In fact, 'wabe' carries similar sounds to 'way', 'wave' and 'web'. Humpty Dumpty explains later that 'wabe' means "The grass plot around a sundial" and that "[it] goes a long way before it, and a long way behind it." (Carroll 1998, 198-199) These aspects bring forth the inquiry into word formation via analogy that Carroll wants to explore in the poem, as well as its recursive patterns and circularity. In a paragraph following the poem, Humpty Dumpty explains many of the terms to Alice. He does so by means of analogies. However, unlike clear comparisons, the descriptions convey complex forms of logic, where meaning is assimilated to several things at the same time.

"That's enough to begin with," Humpty Dumpty interrupted: "there are plenty of hard words there. 'Brillig' means four o' clock in the afternoon - the time when you begin broiling things for dinner."

"That'll do very well," said Alice: "and 'slithy'?"

"Well, 'slithy' means 'lithe and slimy,' 'Lithe' is the same as 'active.' You see it's like a portmanteau - there are two meanings packed up into one word."

"I see it now," Alice remarked thoughtfully: "and what are 'toves'?"

"Well, 'toves' are something like badgers - they're something like lizards - and they're something like corkscrews."

"They must be very curious-looking creatures."

"They are that," said Humpty Dumpty: "also they make their nests under sundials also they live on cheese."

"And what's to 'gyre' and to 'gimble'?"

"To 'gyre' is to go round and round like a gyroscope. To 'gimble' is to make holes like a gimlet."

"And 'the wabe' is the grass-plot round a sun-dial, I suppose?" said Alice, surprised at her own ingenuity.

"Of course it is. It's called 'wabe,' you know, because it goes a long way before it, and long way behind it-"

"And a long way beyond it on each side," Alice added.

"Exactly so. Well then, 'mimsy' is 'flimsy and miserable'. And a 'borogove' is a thin shabby-looking bird with its feathers sticking out all round - something like a live mop." "And then 'mome raths'?" said Alice. "I'm afraid I'm giving you a great deal of trouble." "Well, a 'rath'is a sort of green pig: but 'mome' I'm not certain about. I think it's short for 'from home' - meaning that they'd lost their way, you know."

"And what does 'outgrabe' mean?"

"Well, 'outgribing' is something between bellowing and whistling, with a kind of sneeze in the middle: however, you'll hear it done, maybe -down in the wood yonder - and, when you've once heard it, you'll be quite content". (Carroll 1998, 271-272)

The poem mentions many living creatures, toves, borogoves, raths, the Jubjub bird, the Tumtum tree, the Bandersnatch, described by Humpty Dumpty. 
Along with the Jabberwock, the descriptions of all these creatures function as ekphrastic icons in creating mental images. The physical particularities of these creatures are distinctive and easy to visualize and, thus, memorize, even if the words are made-up and non-existent in the English language. The fact that words may also be used in different morphological roles - verb, noun, adjective - simultaneously contributes to break the indexical logic of narrative deictic (indexical) pointers, materially affecting the relationship between cause and effect, and the temporal sequences of the narrative seem to duplicate, overlap or resonate.

Lewis Carroll's techniques, similar to those used in the $20^{\text {th }}$ century by James Joyce, Jorge Luis Borges, or William S. Burroughs, break alphabetic linear patterns and use language imaginatively (López-Varela 2014a). The purpose is to free discourse from particular ideologies, and call attention to the way meaning is created, frequently under the control of socio-political power structures (López-Varela 2014b). The uncanny (Freud 1990, 335-376) repetition of unknown words and rhythmic patterns produces the impression of a sort of enchantment that suits very well Carroll's mock satire. Tinted with an ironic tone in the use of expressions such "One, two! One, two! And through and through / The vorpal blade went snicker-snack / He left it dead, and with its head / He went galumphing back", and the following stanza: "And hast thou slain the Jabberwock? / Come to my arms, my beamish boy! / O frabjous day! Calloob! Callay! / He chortled in his joy." Semantic cohesion is maintained because alien words are intercalated with those belonging to the English language, particularly in the section just quoted, where the killing of the monster is described in words such as "sword in hand", "eyes of flame" "blade", "through and through", "blade", "dead", "head", "slain".

Carroll's work seems to inaugurate a period that culminated in the language and inter-art explorations of the $20^{\text {th }}$-century. Many avant-garde experiments cultivated crossings not only between poetry and the visual arts but including other arts (see for instance work by Marcel Duchamp or Francis Picabia). The Futurists, for instance, were open to multi-sensory experiments, particularly the impact of typography, ink colours, typefaces, paper texture, book-binding techniques, etc. Many of these inter-art experiments brought to the fore the material aspects of language by focusing on graphic coding, the acoustic and the visual. 


\section{EKPHRASIS IN THE $20^{\mathrm{TH}}$ CENTURY}

The gradual re-evaluation of the visual arts in the $20^{\text {th }}$ century was also influenced by the development of technologies that enabled the cheaper reproduction of images - photography, moving pictures or cinematography and, more recently, digitalization and online technologies. There innovations enabled a greater interplay of perceptual modes, enhancing diverse forms of emotional and aesthetic charge, alternating between showing (mimesis) and telling (diegesis), and enabling the projection of simultaneous occurrences in narrative, for instance, by borrowing techniques from montage in the visual arts and sculpture. In particular, the physical/material boundaries were perceived as capable of enabling certain sets of relations.

In the second half of the $20^{\text {th }}$ century, the discussion on ekphrasis focused more and more the antagonistic struggle between oral forms and written literacy in postcolonial environments, and between word and image/icon as socially and ideologically motivated (Mignolo 1989, 58, 62; Ong 1982) W.J.T. Mitchell explained that "The real question [...] when confronted with these kinds of image-text relations is not "what is the difference (or similarity) between the words and images?' but 'what difference do the differences (and similarities) make?' That is, why does it matter how words and images are juxtaposed, blended, or separated?” (1994, 91) Ernest B. Gilman diverts from Leo Spitzer and Murray Krieger's on the centrality of language in giving voice to images, discussing the imperialism of language as central to inter-art comparisons $(1989,23)$ Similarly, Scott Grant F. Scott sees ekphrasis as appropriation of the "visual other" and as an attempt to "transform and master the image by inscribing it." (1991, 303) Likewise, Jerome McGann (1993) studied the remediation ${ }^{3}$ of aspects from the oral tradition of knowledge transmission in the Western world, as printed culture became widespread. In turn, Katherine N. Hayles $(1984,1990)$ has focused on the differences and parallelisms between scientific discourse, grounded on forms of visibility and experimental proof, and the artistic realm, where, until the $20^{\text {th }}$ century, attention was directed away from the materializations and configurations of writing - print, colour, illustrations, fonts, and so on.

With digitalization, the increasing use of montage and other techniques involving several perceptual modes (mainly visual and tactile), along with the development of software that has made possible the articulation of multiple planes, some of them interactive, has opened online and digital art works to

3 In relation to the remark that the content of a medium is always another medium formulated by Marshall McLuhan, Jay David Bolter and Richard Grusin call the representation of one medium in another 'remediation', arguing that it is a defining characteristic of the new digital media. (Bolter and Grusin 1999, 45)

International Journal of Transmedia Literacy - 1.1 - December 2015

http://www.ledonline.it/transmedialiteracy/ 
their audiences, posing new questions regarding the structure of knowledge and its ways of transfer. As media evolve, so does the concept of ekphrasis which, in the digital world, embraces poly-sensorial forms of embodiment, discourse and action-performance across sign systems that operate with various types of signs. Most ekphrastic processes continue to follow the cognitive-semiotic patterns of human communication modes, functioning according to notions of similarity/difference, expressed by means of metaphors, based on the replication of patterns and structural analogies, (this is also the way in which the human brain maps information by mirroring it across sense perceptions). (Zlatev 2012) Thus, immersion in the virtual worlds seems 'real' from the point of view of spatial relations. However, the mobilization of time in digital formats is fundamentally different. (Flores 2013).

There is also the question of the emotional aspects of artistic communication, neglected for many years. Gilles Deleuze and Felix Guattari situate artistic practices outside mimesis, explaining that their purpose is to find and cultivate what they term 'percepts' which, unlike the usual perceptive mechanisms, free themselves from consciousness and from references to the objects in the world in an attempt to create something never felt or represented before (Deleuze et Guattari 2005, 155; Deleuze et Guattari 1980, 173) Thus, modern art includes geometric and physical imperfections, anomalies that separate it from any model (anology), from anything felt or lived before. (Deleuze et Guattari 2005, 168)

Indeed, Deleuze and Guattari's ideas seem at home in the work by Czech poet and filmmaker Jan Švankmajer. A leading figure in avant-garde cinema and a member of the Prague surrealist group since the early 1970s (Hames 1995, 2, 100) Švankmajer's provocative works convey statements of resistance in the changing political climate of the Czech Republic over the past four decades. Censored and banned for some years, during his time out of cinema Švankmajer channeled his artistic energy into other projects like collages, graphics, and various sculptures drawings, and puppets. His work bridges the gap between live-action and animated cinema, the real and unreal, narrative and non-narrative, providing an interesting study of filmic ekphrasis.

One of Švankmajer's primary concerns is the inner (emotional) life of people and objects, discussed mainly in terms of suppressed impulses related to sexuality, violence, and fear. He consistently depicts objects as having or coming to life, producing a bizarre and uncanny effect. His early association with puppetry and theater, his education at the Institute of Applied Arts in the early 1950s, and his work at the Theatre of Masks, the Black Theatre, or the Lanterna Magika Puppet Theatre, have no doubt influenced Švankmajer's art practices. In his movies, objects have several functions: some appear act as intermedial/intertextual pointers, referring to other works of art with 
special historical significance; others function as markers of space and time; some objects come to life by virtue of the soundtrack; the purpose of their false animation is to point out aspects of meta-representation, questioning the border between the real and the virtual.

Žvablav aneb šatiky Slaměného Huberta ("Nonsense or the small clothes of Straw Hubert') written and directed by Švankmajer and produced by Erna Kmínková, Marta Sichová and Jirí Vanek, is a 1971 fourteen minutes long short featuring colour stop-motion animation. The title (Žvablav means more or less 'nonsense') also alludes to the first Czech translation of Lewis Carroll's poem "Jabberwocky". The character of Straw Hubert comes from a children's story written by Czech surrealist Vítězslav Nezval in 1936 and illustrated by Jičí Trnka: Anička skř́tek a slamĕný Hubert ["Elfin Annie (or Little Anya) and Straw Hubert"]. The story bears some resemblances to Carroll's poem, and uses the metaphor of straw to signify the lack of certain inner qualities, as in the novel The Wonderful Wizard of Oz (1900) by Lyman Frank Baum.

Švankmajer's movie is divided in eight parts. The opening scene (part one) displays a child's buttocks being spanked along with the movie credits and music by Zdeněk Liška. The film explores the degradation of the subject in the process of socialization by turning back to the world of a Victorian children who has to follow certain rules and roles. (Figure 1)

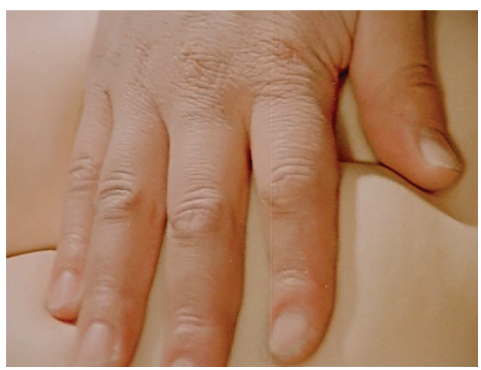

Figure 1 - Jan Švankmajer "Jabberwocky" Part 1.

In part two minute 0.32 , Carroll's poem "Jabberwocky" is read by the voice of an unseen young girl. At the same time, a wardrobe is shown flying through a forest of (Tumtum?) trees. As it glides towards the camera and opens up, the viewer travels back into a Victorian playroom under the supervision of a paternal figure in a portrait, upon which the camera lingers at various times. Initially the objects seen are associated to the world of women. Articulated dolls are a metaphor for the way the female body is manipulated by family life and society. The eyes of the stern patriarch cast a disciplinary glance over the whole sequence during which "Jabberwocky" is read as a sort of enchant- 
ment or spell casted over the nursery, bringing the objects to life: children's clothes that arise from a washbasin, the furniture, a pram, a rocking horse, a doll's house, little toy soldiers. As they come to life, these objects recall the odd beings that populate Carroll's poem and Alice's narrative. (Figure 2)

By the time the poem finishes in part three (minute 4:49), the room is almost empty of objects, but music returns and more objects come to life as if from nowhere. This part ends with the image of a small wall made of puzzle cubes that reminds the viewer of a similar scene in Mary Poppins' movie. (Figure 3) The wall becomes a two-dimensional labyrinth in part four (4:506:59), where a trail of ink from a fountain pen struggles to find its way tracing in silence a solitary line under the supervision of a pair of eyes under spectacles. Before it finds the exit out of the maze, a black cat destroys the puzzle wall and the labyrinth within, and with it any attempt for the ink line to find its way out. This sequence is repeated in the following parts of the movie creating a sense of claustrophobic confinement.

As the music returns in part four, dolls are multiplied as if they were Russian dolls giving birth, coming out from each other's bellies. Soon, they are chopped and flattened like pieces of steak, ironed as clothes, and boiled to the sound of playful music. The smallest dolls are cooked and eaten by the larger ones. This act of cannibalism carries connotations of self-alienation, and the succession of scenes related to the birth of dolls is connected to the world of women and their sexuality. (Figure 4)

Women were responsible for clothing of the entire household and doing the washing, drying, folding and ironing. Initially dolls are perceived as playthings that symbolize women's childhood, but as they become self-animated, they lose their innocence, exposing their sexuality and being chastised (dismembered and cannibalized) by the larger dolls.

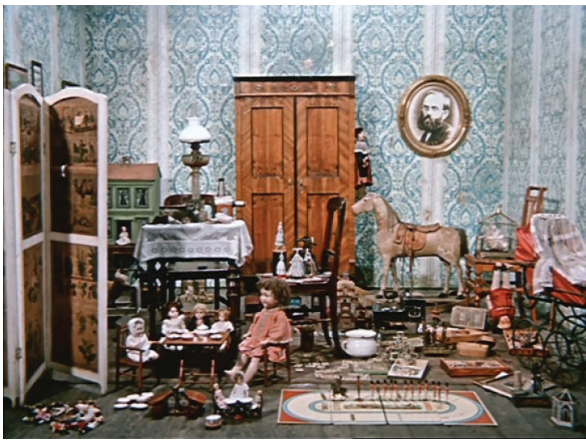

Figure 2

Švankmajer "Jabberwocky" Part 2.

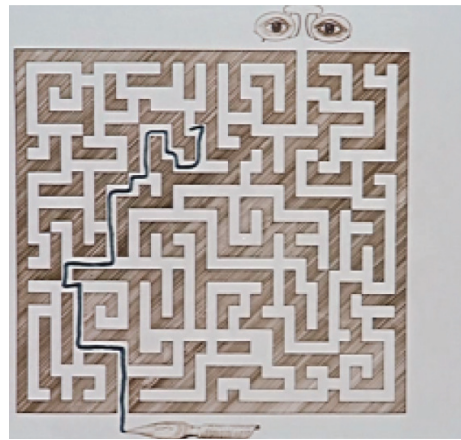

Figure 3

Švankmajer "Jabberwocky" Part 3. 


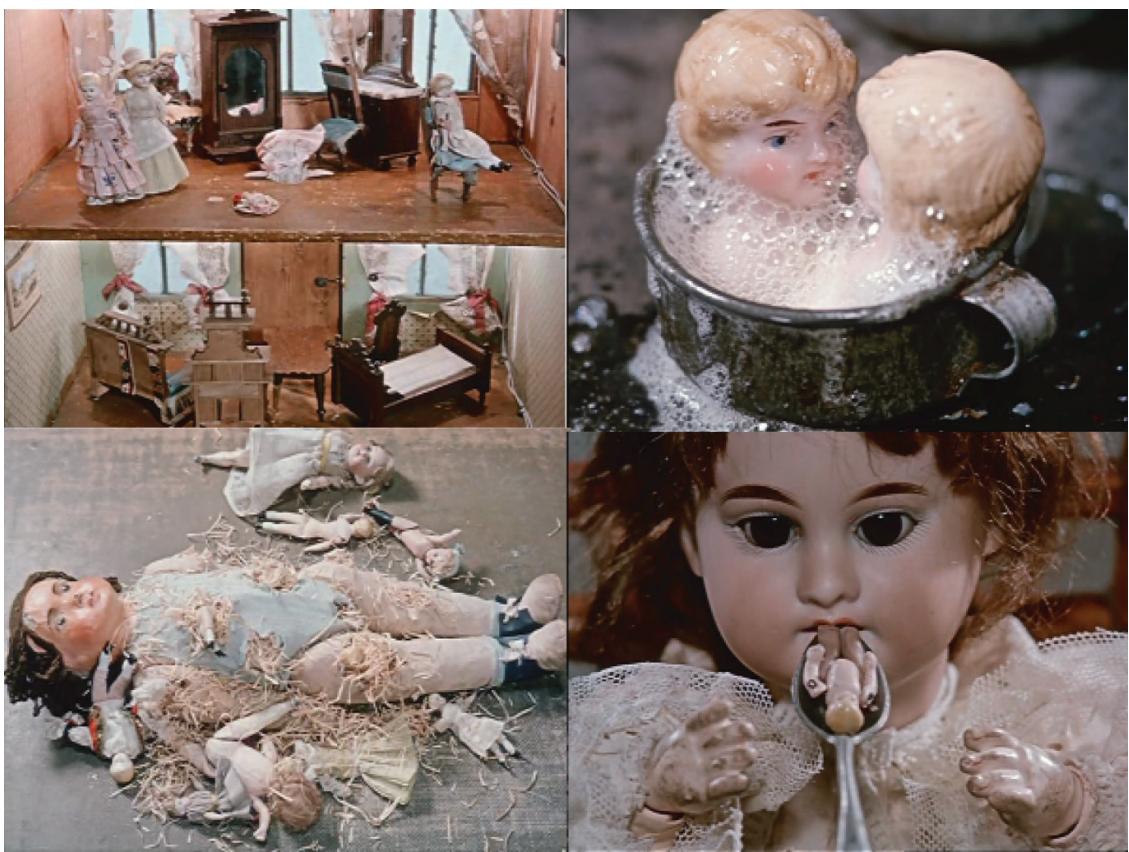

Figure 4 - Švankmajer "Jabberwocky" Parts 3-4.

The Greek philosopher Socrates, whose mother was a midwife, used to draw parallels between the birthing of ideas by means of his teaching method and the delivery of babies. Continuing the work of his teacher, Plato's allegory of the cave exposes people's bondage to reality as a visual illusion, that of the shadows that the fire throws on the opposite wall of the cave. Visual proof (as in the empirical method based also on analogy) can never be a fundament of truth. But, according to Plato, "Everything that deceives may be say to enchant," $(2009,209)$ so that the world of appearances may have a seductive power to which people hold on to as if spellbound. Švankmajer's movie inverts this pattern by showing that although the objects in the wardrobe (which reminds of the one that leads the children into the world of Narnia in C. S. Lewis's novel The Lion, the Witch and the Wardrobe. The Chronicles of Narnia. 1950, 130-131) seem part of an imaginary world, this apparent fantasy may, in fact, show aspects of reality of which the viewer was previously unaware.

The puzzle-wall is the stuff from which new movie images are formed, creating a sort of circular spell from which there seems to be no escape, for everytime the maze appears the viewer anticipates the cat's irruption. (Figure 5) 


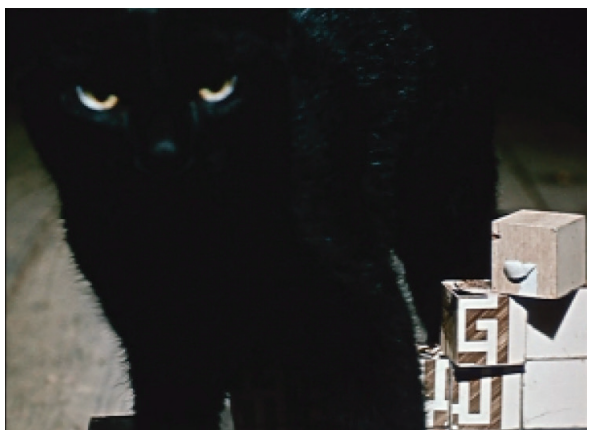

Figure 5. Švankmajer "Jabberwocky" Part 4.

Švankmajer's movie subverts patterns of order and disorder in several ways and at various levels. For instance, he may use formal aspects, such as the introduction of self-reflective loops that break the linearity of the movie narrative sequence (i.e. the repetition of the wall/line/labyrinth scene). At the thematic level, Švankmajer includes the cheerful music, children's playthings, and grotesque images that border the surreal, such as the dolls giving birth and feeding upon one and other.

In part five (7:00-9:11) attention shifts to boys' education. There is a series of symbols of manhood such as the hobby horse and the sailor suit filled with an invisible body. The collection of tiny tin soldiers, neatly aligned, connects the viewer to the military world of order. It also opens up new intertextual storylines to other similar stories (i.e. it comes to mind the Danish story by Hans Christian Andersen "The Steadfast Tin Soldier" 1838). However, the association between the little tin soldier and food (in Andersen's story the soldier is eaten by a fish) is not as explicit as in the case of the images of the cannibalized dolls. (Figure 6)

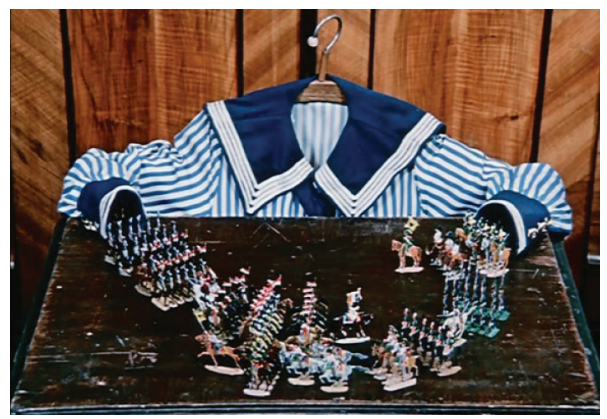

Figure 6. Švankmajer "Jabberwocky" Part 5. 
In Carroll's poem, portmanteau words with multiple meanings are used to break the linear and unique meaning of alphabetic discourse. In Švankmajer's movie a similar effect is achieved by means of images, oddly contextualized in uncanny situations or bizarre sequences that break the usual cause-effect relations that populate the world of consciousness and rationalism. Indeed, the movie presents many examples of simultaneous patterns that produce strange doublings and ambiguities. The most obvious one the puzzle-cat sequence.

In part six (9:12-10:42) violence escalates as a knife's handle (that brings back the corkscrew in Carroll's poem) in the shape of a woman's body who dances a weird waltz during which the handle gets killed by the blade. The image of the severed handle lying on a lace tablemat covered in fresh blood resembles a sexual toy and brings to the fore once more the relation between violence, sex and women submission. It also signals back to Carroll's poem that tells the story of a decapitated monster. This scene connects Švankmajer's possible interpretation of Carroll's "Jabberwocky" in the context of Through the Looking-Glass, and What Alice Found There, bringing forth Freudian associations in relation to the topic of authority, order subversion and child's play.

The pages of school notebooks become Origami (Japanese paper-craft) ships and aeroplanes in section seven (10:43-12:37). The man in the portrait sticks out his tongue and spits out dominoes. The ending, in part eight (12:3813:20), shows the ink line finally freeing itself from the puzzle wall-maze of life and escaping the black cat. To the sound of happy tunes, the line moves to the portrait of the bearded man and, defiantly, it scribbles all over the figure of authority before fleeing out of a window that brings to mind Picasso's blueperiod painting "Women at the Window" (1925). The squadron of paper planes also flies out, and the plutonian cat is seen in a cage within the wardrobe where the children's clothes are now neatly folded. (Figure 7)

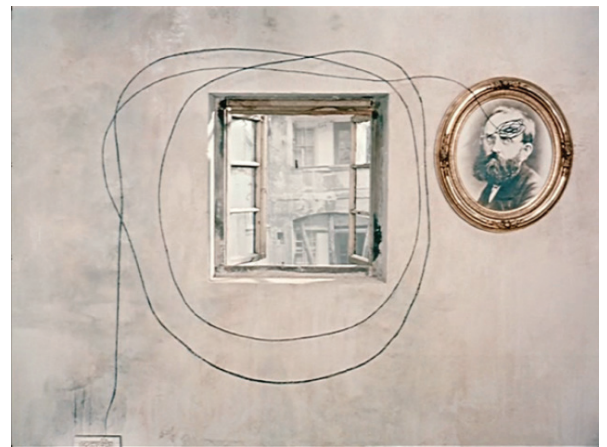

Figure 7. Švankmajer "Jabberwocky" Part 8. 
Like Carroll's poem, Švankmajer's "Jabberwocky" is a compendium signs in the form of icons (images), symbols (the reading of the poem) and indexes (intertextual and intermedial pointers) that interconnect past, present and future. Much of its strength lies in the grotesque and baroque excess of signs that overflows the viewer. The effect of 'strangement' or 'defamiliarization' disrupts everyday analogy patterns. The linear narrative is punctured by ironic doublings, many of them arising from other storylines within the main theme. These new threads are not merely intertextual allusion to other texts. There is also a prominent use of images and prints of real outdoor scenes and people's faces in the form of photographs, daguerreotypes, painted portraits and sketches, at various scales and levels of detail. They contribute to the eerie atmosphere half reality half fantasy, where ambiguity, loops and repetitions that "go a long way before it, and long way behind it", as Carroll's poem reads, satirically reinforce the central idea: the awareness of order submission and mindless mimicry implicit in the socialization process that turns humans into automatons. There is, however, a note of hope at the end of "Jabberwocky". The idea that with the cat caged and the monster decapitated, the unguarded maze can perhaps be fled.

\section{EKPHRASIS IN THE $21^{\text {ST }}$ CENTURY}

Undoubtedly inspired in Lewis Carroll's work, Simon Biggs' digital installation reRead offers several ways of inquiry into the workings of ekphrasis and analogy. reRead was presented at the conference of the Electronic Literature Organization held at Brown University (Providence RI, US) in 2010.

Biggs' art-works seek to evoke a subjective failure of differentiation and re-posit the self as non-singular, de-centered and distributed. They also reveal the tensions among different perceptual modes and highlights the incapacity of any one medium to capture the complete multimodal nature of perception, introducing variations in natural language in order to display its monstrous non-meaningful qualities when 'carried over' to unexpected positions.

In his 2008 essay "OntoPoetics," Simon Biggs explains that he seeks to "address this focus through the use of interactive systems, where the relationship between the viewer and the artwork is explicit and active." (n/p) Biggs is therefore aiming at presenting individual subjectivities as constructed in performative processes that operate within a digital environment and in interaction with other subjectivities. "The auto-linguistic artworks I make map an exploration of the manner in which this dynamic of differentiation through reading/writing can be disturbed and opened up as a conscious process." $\mathrm{He}$ 
adds that the primary element in this strategy is the use of auto-generative texts in order "to create instances of textuality where the text is written of itself. That is to say, the text is generated as a function of language itself. Authorial intent is absent, replaced by a process of auto-generative writing." (n/p)

Thus, in Biggs' auto-poetic artworks, the viewers are able to observe themselves reading/writing self-generating texts. Attention is drawn to the fact that new media do not show how things 'are' but how things 'operate,' and many times these operations are enabled by the machine code and allow for self-reflexive configurations, alien to the linear patterns of narratological cause-effect relations.

In reRead, the reader/viewer finds herself facing a screen where autogenerative texts are reflected from a projector connected to a computer situated just behind the viewer. Unlike ordinary projections, here the letters appear backwards. Initially the viewer is unaware of this fact, as she looks at the symbols from what it seems an unknown unreadable language. They move rapidly into shapes that appear to be larger units of text. Eventually, they are recognized as letters of the Latin alphabet and as some kind of narrative pattern. Cognitive scientists have explained that the brain works in holistic self-organizing processes that complete perceived information even before full perception has been accomplished. Under the principle of psychophysical isomorphism, the human eye may not see objects in their entirety but perceiving an aggregated of parts, it would fill up the whole. Some other mechanisms seem to copy information across perceptual regions by means of mirror-neurons and other ways in which the various sensorial modalities communicate and exchange information. (Zlatev 2012)

The eyes follow certain reading directions depending on the language (some a written from left to right; others in the inverse; yet others are read up-down). Printed texts are not read in the same way as texts displayed on a computer screen, where we might need to scroll down instead of passing the pages. Attention is captured more rapidly in the perception of movement. When the text moves, as in reRead, the reading experience becomes more difficult. Kinetic texts might cause the reader to pause and think, unable to follow alphabetic and narrative sequences.

reRead complicates reading even more by incorporating the image of the viewer onto the text displayed on the screen as she moves towards it. This is done by means of the computer Webcam connected to the projector situated behind the viewer as she faces the screen. The art-work confronts the audience with an inquiry into the textual and iconic nature of language, following Biggs ideas: "Art is the human activity which can confound basic sense and allow us to see things in a way we might otherwise not have considered". He adds that "Art functions as a sort of meta-language", for "It is in the creation of disjuncture between the thing and its representation that we come to see the 
thing and its relation to other things (particularly ourselves) anew. In seeking to disturb the manner in which we see things, and thus our accepted notion of self as constructed through seeing, the objective to destabilize our sense of self can be met." $(\mathrm{n} / \mathrm{p})$

reRead also brings to the fore a questioning of the Self, exemplified in the perceptual confusion which affects the viewers, exposing their Webcam images as fragmented text pieces that disrupt the random pseudo-narrative projected onto the screen by the computer. Initially blind to the meaning of the text that appears backwards on the screen, the viewer engages in action in order to understand, to see. The screen becomes a looking-glass where Alice, the viewer, inscribes herself onto Biggs' text. As she moves, her actions incorporate the motions of her body within the random backward awkward movement of letters (perhaps words) in a silent performance of text and images.

In Biggs' reRead, vision serves as a sort of third-person bridging modality that links first-person information (self-awareness) to others. Vision is taskoriented and goal-directed, that is, concerned with obtaining information for the discrimination, identification and categorization of objects for later use. In the case of Alice, as onlookers watch her move in front of the mirror-like screen, they also try to understand her intentional actions, that is, to make sense of her motivations and decisions in moving here or there. This contextualization requires a certain degree of 'trust', or 'cooperative principle', as pragmatist Paul Grice would have put it. The trust placed by reRead onlookers on Alice's performance depends on aspects that range from the contextual to prior knowledge of similar situations. Age is an important factor in engaging in more active behavior. Older onlookers might settle for watching Alice perform the act. The more active and adventurous might decide to have a go themselves. Those not present at the time of the performance, for instance those seeing through my eyes in reading this text, will need to trust my telling.

The process of intermedial ekphrasis, as staged in Biggs' installation, serves also as a cognitive tool. The artist seeks to challenge human modes of analogic perception by means of complicating ekphrastic processes. He succeeds in capturing attention and awareness. The viewer discovers that human communication relies on analogic principles, either in showing (mimesis), as in performances and gestures, or in telling (diagesis) as in discourse. Unlike gestures, which rely on the contiguity of vision, verbal communicative acts that take place in the present may posit the subject's experience in a different space-time plane (i.e. the past or the future) and thus, in a new belief mode, distinct from that of the original occurrence. Once verbal language is introduced, situations are (re)presented (reRead). The addressee or reader visualizes the scene in her own space-time framework, implying a willing intersubjective coordination between speaker/writer and addressee/reader. 


\section{CONCLUSION}

The examples presented in this paper, Lewis Carroll's poem "Jabberwocky", Jan Švankmajer's film by the same title, and Simon Biggs' installation reRead provide a glimpse of the metamorphosis that the processes of ekphrastic have suffered under changing media formats. The three art-works offer examples of how art can break patterns of analogy present in human communication modes. In drawing attention to non-linear structures, recursive and self-reflexive forms of intermedial communication, the works discussed question the scientific episteme, modelled on analogic principles, and offer different ways of imaginative projections. The ironic commentary, as in the case of Carroll, an escape into the realm of fantasy, in Švankmajer's movie, and the use of hybrid forms that combine the analogic patterns of human biology with digital coding, in Biggs' installation, the three open the art work to novel ways of audience interaction.

\section{ACKNOWLEDGMENTS}

To Simon Biggs for copyleft of his images.

To Ministerio de Economía y Competitividad Gobierno de España for a research grant at Harvard University in 2013.

To Prof. David Damrosch, Department of Comparative Literature at Harvard University for hosting my research visit in 2013.

\section{REFERENCES}

Aristotle. 1987. Poetics. Trans. Stephen Halliwell. Chapel Hill: University of North Carolina Press.

Biggs, Simon. 2009. reRead. http://ai.eliterature.org and Biggs personal webpage. Last access August 25, 2014. URL: http://www.littlepig.org.uk/reRead/reRead.htm and http://www.youtube.com/watch?v=OSias0PZ6js.

Biggs, Simon. 2008. "Ontopoetics." Biggs personal webpage. Last access August 25, 2014. URL: http://www.littlepig.org.uk/texts/ontopoetics.htm.

Bolter, Jay David, and Richard Grusin. 2000. Remediation. MIT Press.

Brooke, Michael. "Jan Švankmajer: Alchemist of the Surreal” Last access August 25, 2014. URL: http://www.illumin.co.uk/svank

Bute, Michael. 1997. A Town like Alice's. Sunderland: Heritage Publications.

Campbell, David. 1991. Greek Lyric: Stesichorus, Ibycus, Simonides, and Others. Vol. III. Harvard University Press: Loeb Classical Library. 
Carroll, Lewis. 1998. Alice's Adventures in Wonderland and Through the LookingGlass. Wordsworth Editions.

Deleuze, Gilles, and Félix Guattari. 2005. Qu’est-ce que la philosophie? Paris: Editions de Minuit.

Deleuze, Gilles, and Félix Guattari. 1980. Mille Plateaux. Capitalisme et schizophrénie 2. Paris: Editions de Minuit.

Drucker, Johanna. 1995. The Alphabetic Labyrinth: Letters in History and Imagination. Thames \& Hudson Ltd 1995.

Elleström, Lars. 2014. Media Transformation: The Transfer of Media Characteristics Among Media. New York: Palgrave Macmillan.

Freud, Sigmund. 1990. "The Uncanny." Freud, Art and Literature: Jensen's Gradiva, Leonardo Da Vinci and Other Works. Trans. James Strachey et al. Ed. Albert Dickson, 335-376. Harmonsdworth: Penguin.

Flores, Leonardo. 2013. "Digital Textuality and its Behaviors.", Intermedial Studies, edited by Asunción López-Varela. Special issue. Journal of Comparative Literature and Aesthetics 36 (1-2): 123-139.

Gadamer, Hans-Georg. 1960. Wabrbeit und Methode. Tübingen: Mohr.

Gale, Monica R. 2007. Oxford Readings in Classical Studies: Lucretius. Oxford: Oxford University Press.

Gardner, Martin. 1999. The Annotated Alice: The Definitive Edition. New York: Norton.

Gilman, Ernest B. 1989. “Interart Studies and the 'Imperialism' of Language," Art and Literature I, edited by Wendy Steiner. Special issue. Poetics Today 10 (1): 5-30.

Grant, F. Scott. 1991. “The Rhetoric of Dilation: Ekphrasis and Ideology.” Word E Image 7 (4): 301-310.

Green, Roger L. 1970. The Lewis Carroll Handbook. London: Dawson of Pall Mall.

Hames, Peter. 1995. Dark. Alchemy: The Films of Jan Švankmajer. Westport: Praeger.

Hayles, Katherine N. 1984. The Cosmic Web: Scientific Field Models and Literary. Strategies in the Twentieth Century. Ithaca: Cornell University Press.

Hayles, Katherine N. 1990. Chaos Bound: Orderly Disorder in Contemporary Literature and Science. Ithaca: Cornell University Press.

Heffernan, James A.W. 1993. Museum of Words: The Poetics of Ekphrasis from Homer to Ashbery. Chicago and London: University of Chicago Press.

Jung, Carl G. 1938-40 (1986). "Psychology and Religion.” In Collected Works Vol. 11, edited and translated by R.F.C Hull, 3-105. London: Routledge \& Kegan Paul.

Krieger, Murray.1992. Ekphrasis: The Illusion of the Natural Sign. Baltimore and London: Johns Hopkins University Press.

Lewis, C. S. 1950. The Lion, the Witch and the Wardrobe. The Chronicles of Narnia. New York: Harper Collins. 
López-Varela Azcárate, Asunción. 2004. Embers of Time: a pluridisciplinary exploration of the crisis of the representation of time in science and literature. Madrid: Universidad Complutense.

López-Varela Azcárate, Asunción. 2014a. "Antiabecedarian Desires: Odd Narratology and Digital Textuality," edited by Carolina Fernández Castrillo, 29-55 Special issue. Icono 14. 12.2. doi: 10.7195/ri14.v12i2.727.

López-Varela Azcárate, Asunción. 2014b. "Meta-language in Lewis Carroll's Jabberwocky and Simon Biggs' reRead" CLCWeb Journal of Comparative Literature and Culture 16.5. http://docs.lib.purdue.edu/clcweb/vol16/iss5/.

Markiewicz, Henryk. 1987. "Ut Pictura Poesis: A History of the Topos and the Problem," New Literary History 18 (3): 535-558.

McGann, Jerome. 1993. Black Riders: The Visible Language of Modernism. Princeton: Princeton University Press.

Mignolo, Walter. 1989. "Literacy and Colonization: The New World Experience." In 1492-1992: Re/discovering Colonial Writing, edited by Rene Jara and Nicholas Spadaccini, 51-96. Hispanic Studies 4. Minneapolis: Prisma Institute.

Mitchell, W.J.T. 1994. Picture Theory. Chicago: Chicago University Press.

Mitchell, W.J.T. 1986. "Space and Time: Lessing's Laokoon and the Politics of Genre," In Iconology: Image, Text, Ideology, 95-115. Chicago: Chicago University Press.

Ong, Walter J. 1982. Orality and literacy: the technologizing of the Word. London: Routledge.

Peirce, Charles S. 1955. Philosophical Writings of Peirce. New York: Dover Publications, Inc.

Plato. Timaeus. Last access August 25, 2014 http://www.gutenberg.org/ebooks/1572.

Plato. 2009. The Republic. Translation by Benjamin Jowett. New York: Kaye Dreams Novel Art.

Rasula, Jeff and Steve McCaffery. 1998. Imagining Language. MIT Press.

Spitzer, Leo. 1955. “The 'Ode on a Grecian Urn,' or Content vs. Metagrammar," Comparative Literature 7 (3): 203-225.

Steiner, Wendy. 1982. The Colors of Rhetoric. Chicago: Chicago University Press.

Švankmajer, Jan. 2007. The Complete Short Films (DVD), London: British Film Institute.

Trahndorff, Karl Friedrich Eusebius. 1827. Ästhetik oder Lebre von Weltanschauung und Kunst. Berlin: Maurer.

Da Vinci, Leonardo. 1992. Paragone: Critical Interpretation with a new Edition of the Text in the Codex Urbinas, edited by Claire J. Farago. Leiden: E.J. Brill.

Wettlaufer, Alexandra. 2003. In the Mind's Eye: The Visual Impulse in Diderot, Baudelaire and Ruskin. Amsterdam: Rodopi.

Zlatev, Jordan. 2012. "Cognitive Semiotics: An emerging field for the transdisciplinary study of meaning." Public Journal of Semiotics 4 (1): 2-24. 